\title{
Using simulation to assess undergraduate nursing students' competency with medication administration to a limited- English language proficiency patient
}

\author{
Mary J o C Stanley, Lynn Philips, Ben Galatzan \\ Beth-EL College of Nursing and Health Sciences, University of Colorado at Colorado Springs, Colorado, United States. \\ Correspondence: Mary Jo C Stanley. Address: 1420 Austin Bluffs Parkway, Colorado, United States. Email: \\ mstanley@uccs.edu
}

Received: December 30, 2013

Accepted: February 20, $2014 \quad$ Online Published: March 4, 2014

DOI : $10.5430 /$ jnep.v4n5p29

URL: http://dx.doi.org/10.5430/jnep.v4n5p29

\begin{abstract}
Background/Objectives: Medication errors continue to be an area of concern in health care and are a significant cause of morbidity and mortality in both inpatient and outpatient settings. Little consideration has been given to the role of the patient in the medication process; patients with limited-English language proficiency (LEP) may be at risk for medical errors and drug complications. The purpose of this research study is to assess undergraduate nursing students' competency with medication administration to a simulated patient with LEP.

Methods: A non-experimental quantitative design using the Medication Administration Safety Assessment Tool (MASAT) (Copyright (C) 2013 Goodstone \& Goodstone) for student competency in medication administration performance was conducted in a simulation environment. Qualitative data was also collected during debriefing for questions specific to safety, medication administration, and barriers related to care.

Results: Student scores on the MASAT identified a less than expected probability of success. Students' performance did not show proficiency in the six rights of medication administration; in addition, students' were inattentive to the language needs of a LEP patient.

Conclusion: Results from this study indicate further experiential learning activities may be necessary to reinforce safety in medication administration. Students were not attentive to the language needs of the simulated patient and may require additional learning opportunities through simulation to assist students in responsive behaviors that support LEP patients.
\end{abstract}

\section{Key words}

Medication administration, Medication errors, Limited- English language proficiency, Human patient simulation

\section{I ntroduction and background}

Medication errors continue to be an area of concern in health care and are a significant cause of morbidity and mortality in both inpatient and outpatient settings. The Institute of Medicine's seminal report, To Err Is Human: Building a Safer Health System, estimates 98,000 deaths annually are attributed to medication errors within the United States ${ }^{[1]}$. One out of every five medication doses given in the hospital setting will result in a medication error ${ }^{[2]}$. The Joint Commission ${ }^{[3]}$ has identified procedural complications and communication as the most cited cause of medication errors accounting for $80 \%$ 
of sentinel events. Medication errors can occur for a variety of reasons including prescribing, transcribing, dispensing, selection, ordering, and administration; however, medication administration is predominately the nurse's responsibility and accounts for $53 \%$ of all errors ${ }^{[4,5]}$.

Adherence to the five rights of medication administration has been the guiding framework for nurses to ensure safety in medication administration. Over the last decade, additional categories for medication administration rights have been put forth in an effort to promote continued safety in the medication administration process; these additional rights include: documentation, reason, action, form, and response ${ }^{[6]}$. For this study, the six rights of medication administration will be used for student assessment and are defined as: the right patient, the right drug, the right dose, the right route, the right time, and the right documentation. The medication rights are part of a system that encourages safety in medication administration ${ }^{[6]}$; however, little consideration has been given to the role of the patient in the medication process ${ }^{[7]}$. The Institute of Medicine ${ }^{[8]}$ states patients with limited-English language proficiency (LEP) are most at risk for medical errors and drug complications. The United States Health and Human Services ${ }^{[9]}$ defines LEP as “...persons who are unable to communicate effectively in English because their primary language is not English and they have not developed fluency in the English language.” Nurses play a key role in patient education and information exchange with language and literacy necessary for effective health communication.

There is a need in schools of nursing for robust education and a focus on patient safety to mitigate medication errors ${ }^{\text {[10-15] }}$. Nursing education must take a judicious look at how medication administration is taught in nursing school. Valdez, de Guzman, and Escolar-Chua ${ }^{[15]}$ found that the majority of medication errors committed by nursing students are due to failures of one of the rights of medication administration. These authors attribute students' learning of medication administration to their clinical setting and classroom education, citing both as failing to offer assurance of competency due to unpredictability of clinical settings and theory-practice gaps. Honey and Lim ${ }^{[16]}$ identify lack of preceptor time and knowledge in the clinical setting as a barrier to teaching students medication administration. To address this concern, Goodstone and Goodstone ${ }^{[17]}$ support the use of human patient simulation (HPS) with medication administration. Simulated medication administration has been shown to increase student confidence and ability to administer medication safely ${ }^{[18]}$. Ford et al. ${ }^{[19]}$ reports that simulation-based education for nurses can significantly decrease $(p<.001)$ medication error rates compared to didactic education. An integrative review reports that realistic simulations requiring medication calculations provide the best learning outcomes and increased accuracy for nursing students ${ }^{[20]}$.

The purpose of this research study is to assess undergraduate nursing students' competency with medication administration to a simulated patient with LEP. The research question guiding this study is: What types of medication errors occur in the medical-surgical simulation setting with undergraduate nursing student when caring for a Vietnamese patient? This pilot project assisted with determining adequacy of the Medication Administration Safety Assessment Tool (MASAT) (Copyright ( 2013 Goodstone \& Goodstone, Permission for use Granted) ${ }^{[17]}$ and the six rights of medication administration as an evaluative measure of competency in undergraduate nursing students. In addition, mild deception was used in this study with the intent to evaluate the influence of a LEP patient as a possible barrier to medication administration.

\section{Methodology}

\subsection{Research design}

A non-experimental quantitative design using the MASAT to measure student competency in medication administration performance was conducted in the simulation environment. Qualitative data was also collected during debriefing. Undergraduate nursing students from a baccalaureate college in the Rocky Mountain region of the United States were solicited to participate in the study. These students were in their second year of nursing training, taking their second medical-surgical clinical course, and participating in their eighth simulation scenario. A total of 47 students out of a 
possible 57 agreed to participate in the study through signed consent. All students were 18 years of age and older. IRB approval for this pilot study was obtained.

\subsection{Simulation and debriefing}

All data for the study was obtained during the students' simulation experience. Students who agree to participate in the study were provided with a demographic survey to complete at the time of simulation. Participation in high-fidelity simulation was a requirement for the students' medical-surgical course; those students who did not wish to participate in the study could opt out of the research, but were required to participate and complete the medication administration simulation. The simulation contained the same scenario for all students. Each scenario consisted of one student participating in a medication administration simulation with a LEP HPS. The students were informed that the manikin was a Vietnamese male who was on a business trip to the United States having arrived 48 hours prior when he presented in the emergency room with leg pain and shortness of breath. The simulation scenario took place in the simulated hospital room. The students were instructed to assess the patient, call the charge nurse to check calculations, obtain the medication, and then administer the medication. Upon review of the patient's electronic record, students' would discover a low anti-Xa assay requiring a Heparin bolus and an increase in the intravenous Heparin infusion rate as directed by the medical orders. The Vietnamese patient, responding via streaming voice technology, was directed to ask questions about the medication and his condition; the patient was to indicate that he spoke and understood only limited English. Student performance during medication administration was scored using the MASAT. Students' MASAT scores were not shared with clinical instructors and students were not informed of their MASAT scores; student scores on the MASAT did not affect course grades.

Debriefing was done after completion of high-fidelity simulation. Questions related to safety, medication administration, and barriers in the care of the patient were discussed with each student. Students were not informed of the intent to study the influence of LEP prior to participating. It was felt that predisposing the students with respect to language specific barriers might influence their response in simulation. A second debriefing session was completed with students immediately following simulation debriefing to clarify the deception. Students were asked not to discuss the study with other students in the class who were participating in the study.

\subsection{I nstrument}

The MASAT is an eight-item instrument measuring student competency regarding the six rights of medication administration. The MASAT is scored dichotomously by an instructor who checks either the yes or no box to indicate competency in achieving each of the eight items. The score is determined by quantity of boxes checked yes, with a total of eight possible points and a range from zero to eight. Goodstone and Goodstone ${ }^{[18]}$ attest to content validity through subject matter expert ratings and pilot testing of the tool to affirm interrater reliability; the MASAT has a Cronbach's alpha of 0.84. Analysis for this study was done using Excel to estimate the measurement error using a binomial distribution.

\section{Results}

Forty seven undergraduate students participated in the medication administration simulation. The population consisted of 9\% males and 91\% females, ranging in age from 20-49 with an average age of 27 years. Eighty seven percent of participants identified themselves as white, 9\% identified themselves as Hispanic, 2\% stated they were Asian, and 2\% American Indian. Forty seven percent of the participants stated they had worked in a health related capacity prior to attending the nursing program with previous experience ranging from 3 months to 20 years; six of the participants had five or more years experience working in a health related capacity.

Student scores on the MASAT identified a less than expected probability of success; students' performance did not show proficiency in the six rights of medication administration. Medication administration errors were determined for all student participants for their medication performance in simulation. Excel's binomial distribution function was used to 
estimate the probability of success (p) in scoring a yes for the MASAT categories. Combined MASAT scores (all eight categories for all 47 participants) determined p to be equal to 0.58 (219 scored yes out of 376 possible attempts) using a $5 \%$ - 95\% confidence interval with a measurement error range of $0.56-0.62$.

To answer the research question: "What types of medication errors occur in the medical-surgical simulation setting with undergraduate nursing student when caring for a Vietnamese patient?" probability of success and measurement error for the eight MASAT categories was calculated (see Table 1).

Table 1. MASAT Categories

\begin{tabular}{|c|c|c|c|}
\hline MASAT & Medication “Rights” & Estimated Probability of Success & Measurement Error Range \\
\hline Category 1 & $\begin{array}{l}\text { Student asks patient to state } \\
\text { name and date of birth }\end{array}$ & $\begin{array}{l}0.56 \\
\text { (26 scored yes out of } 47 \text { possible attempts) }\end{array}$ & $\begin{array}{l}0.44 \text { - } 0.68 \\
\text { Confidence Interval (5\% - 95\% ) }\end{array}$ \\
\hline Category 2 & $\begin{array}{l}\text { Student checked name and date } \\
\text { of birth against MAR }\end{array}$ & $\begin{array}{l}0.26 \\
\text { (12 scored yes out of } 47 \text { possible attempts) }\end{array}$ & $\begin{array}{l}0.17 \text { - } 0.38 \\
\text { Confidence Interval (5\% - 95\% ) }\end{array}$ \\
\hline Category 3 & $\begin{array}{l}\text { Student checked patient's } \\
\text { identification band for name and } \\
\text { date of birth }\end{array}$ & $\begin{array}{l}0.40 \\
\text { (19 scored yes out of } 47 \text { possible attempts) }\end{array}$ & $\begin{array}{l}0.30 \text { - } 0.54 \\
\text { Confidence Interval (5\% - 95\% ) }\end{array}$ \\
\hline Category 4 & $\begin{array}{l}\text { Student checked each } \\
\text { medication from drawer against } \\
\text { MAR for correct drug name }\end{array}$ & $\begin{array}{l}0.57 \\
\text { (27 scored yes out of } 47 \text { possible attempts) }\end{array}$ & $\begin{array}{l}0.47 \text { - } 0.70 \\
\text { Confidence Interval (5\% - 95\% ) }\end{array}$ \\
\hline Category 5 & $\begin{array}{l}\text { Student checked each } \\
\text { medication from drawer against } \\
\text { MAR for correct drug dose }\end{array}$ & $\begin{array}{l}0.57 \\
\text { (27 scored yes out of } 47 \text { possible attempts) }\end{array}$ & $\begin{array}{l}0.47 \text { - } 0.70 \\
\text { Confidence Interval (5\% - 95\% ) }\end{array}$ \\
\hline Category 6 & $\begin{array}{l}\text { Student administered } \\
\text { medication via correct route }\end{array}$ & $\begin{array}{l}0.98 \\
\text { ( } 46 \text { scored yes out of } 47 \text { possible attempts) }\end{array}$ & $\begin{array}{l}0.94 \text { - } 0.99 \\
\text { Confidence Interval (5\% - 95\% ) }\end{array}$ \\
\hline Category 7 & $\begin{array}{l}\text { Student administered } \\
\text { medications at the correct time }\end{array}$ & $\begin{array}{l}0.94 \\
\text { (44 scored yes out of } 47 \text { possible attempts) }\end{array}$ & $\begin{array}{l}0.88 \text { - } 0.98 \\
\text { Confidence Interval (5\% - 95\% ) }\end{array}$ \\
\hline Category 8 & $\begin{array}{l}\text { Student correctly documented } \\
\text { medication MAR }\end{array}$ & $\begin{array}{l}0.38 \\
\text { (18 scored yes out of } 47 \text { possible attempts) }\end{array}$ & $\begin{array}{l}0.28 \text { - } 0.51 \\
\text { Confidence Interval (5\% - 95\% ) }\end{array}$ \\
\hline
\end{tabular}

Students' performed well in the categories of student administered medication via the correct route (category 6) and student administered medication at the correct time (category 7). Questions one through five and eight of the MASAT did not have favorable student performance with an estimated probability of success ranging from $0.26-0.57$ (see Figure 1).

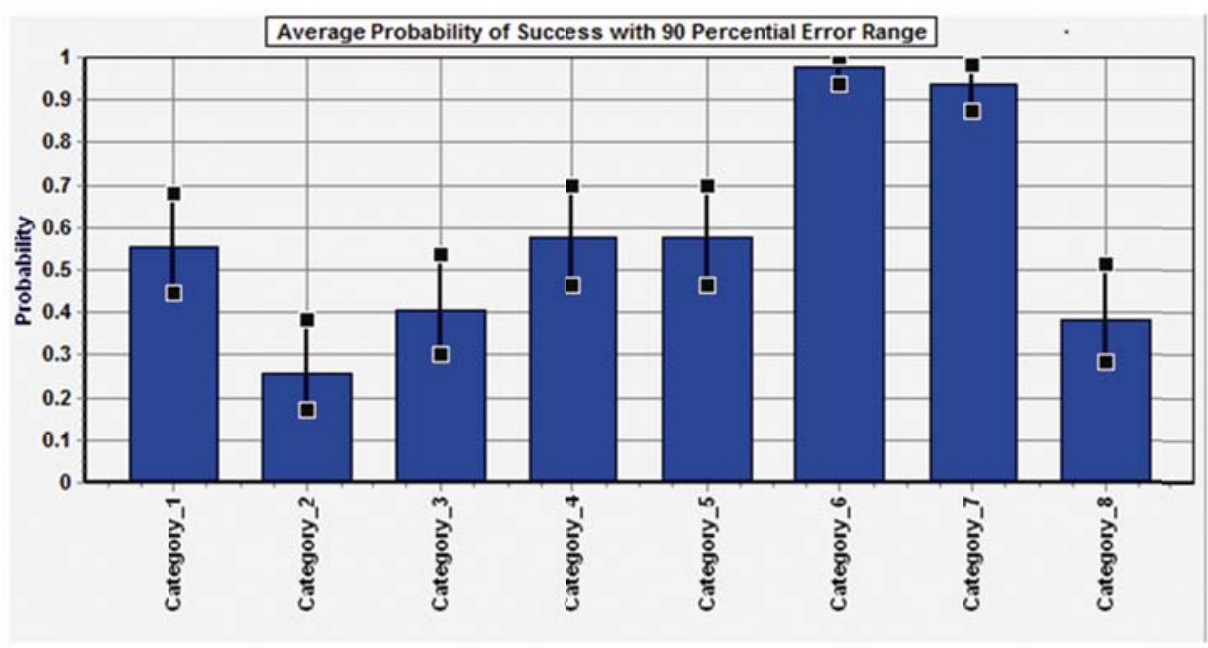

Figure 1. Probability of Success for MASAT Categories 
Debriefing responses were aggregated for each question. Student responses focused on rate of speech and use of medical jargon; few students asked for a translator (see Table 2).

Table 2. Debriefing Questions

\begin{tabular}{|c|c|c|}
\hline Debriefing Questions & Aggregated Responses & Student Comments \\
\hline $\begin{array}{l}\text { Were there any } \\
\text { considerations with } \\
\text { medication instruction } \\
\text { for the patient? }\end{array}$ & $\begin{array}{l}\text { Students acknowledged language barriers and } \\
\text { cultural considerations, but offered no solution; } \\
\text { five students identified using an interpreter/ } \\
\text { translator to ensure patient understanding. Most } \\
\text { students identified procedures such as medication } \\
\text { rights, checking lab values, and assessment as } \\
\text { considerations for care. }\end{array}$ & $\begin{array}{l}\text { "There was a language barrier; I didn’t know if I } \\
\text { needed a translator, and the patient didn't say." } \\
\text { "I had to consider if the patient had any allergies, } \\
\text { bleeding risks, and signs and symptoms of } \\
\text { bleeding. } \\
\text { "I really wanted the patient to understand so I used } \\
\text { simple terms to educate." }\end{array}$ \\
\hline $\begin{array}{l}\text { What barriers did you } \\
\text { encounter in caring for } \\
\text { your client? }\end{array}$ & $\begin{array}{l}\text { Students identified language, culture, and } \\
\text { communication as barriers to patient care. }\end{array}$ & $\begin{array}{l}\text { "There was a language barrier, but it seemed like } \\
\text { he understood } 90 \% \text { of what I was telling him.” } \\
\text { It was difficult to speak with the patient; I had to be } \\
\text { careful and not speak too fast.” } \\
\text { There may have been some cultural barriers; I was } \\
\text { not familiar with Vietnamese.” }\end{array}$ \\
\hline $\begin{array}{l}\text { What procedures did } \\
\text { you follow to ensure the } \\
\text { safety of the patient? }\end{array}$ & $\begin{array}{l}\text { Students had a medical-surgical focus identifying } \\
\text { medication rights, medication calculations, } \\
\text { assessment, and safety items (head of bed low, call } \\
\text { light within reach) as necessary to ensure safety of } \\
\text { the patient. No student identified language or } \\
\text { communication as a necessary component to } \\
\text { ensure safety. }\end{array}$ & $\begin{array}{l}\text { "I checked the ID, explained side effects, increase } \\
\text { HOB, monitored vital signs, and checked if the } \\
\text { patient had questions." } \\
\text { "I double checked the math, assessed the patient, } \\
\text { and checked the oxygen and flow rate." } \\
\text { "What procedures should I have followed?" }\end{array}$ \\
\hline $\begin{array}{l}\text { Do you have any } \\
\text { questions regarding } \\
\text { your performance and } \\
\text { medication } \\
\text { administration with a } \\
\text { limited- English } \\
\text { language proficiency } \\
\text { patient? }\end{array}$ & $\begin{array}{l}\text { Students stated that they did not take into account } \\
\text { language or cultural needs, and that they really } \\
\text { didn't think about this aspect of care. Students } \\
\text { identified being focused on the medications and } \\
\text { the math calculations. }\end{array}$ & $\begin{array}{l}\text { "I did not take into account the cultural needs as } \\
\text { these were standard medications." } \\
\text { "In the future I would ask more questions about } \\
\text { culture and religion; I didn’t really think about it." } \\
\text { "Can I call a translator?” } \\
\text { "I was focused on the medications and the math.” } \\
\text { "How would you approach the cultural issues?” }\end{array}$ \\
\hline
\end{tabular}

\section{Limitations}

This pilot study included a sample size of 47 students from one baccalaureate nursing program. The study used a single site for data collection with limited diversity within the sample. Simulation scenarios were conducted in the simulation center with a high-fidelity manikin and not in a hospital setting. Students had laboratory and clinical exposure to intravenous medication administration, but had not performed this skill in a simulation setting. Students had practiced with the documentation software in the classroom, but not in the simulation setting.

\section{Discussion}

To answer the research question "What types of medication errors occur in the medical-surgical simulation setting with undergraduate nursing students when caring for a Vietnamese patient?” The MASAT tool was used to quantify which medication rights nursing students failed to follow when administering medications to a simulated patient. Consistent with the results from other studies ${ }^{[7,15]}$, a significant number of nursing students committed one or more direct violations of the six rights. Students' scored low in the categories of right drug, right dose, right documentation, and right person. Students did not check drug and dose against the MAR potentially giving medications that were not correct to the patient. Germann, et al. ${ }^{[21]}$ states the need for deliberate practice in teaching to reinforce desired motor skills. Students' actions from this 
study are concerning and warrant investigation into medication administration teaching practices. In addition, it was noted in the simulation scenarios that students did not document the medications given. This may be a limitation of the study as students had limited exposure to the documentation system prior to application in simulation.

Few students checked the name band and date of birth against the MAR. Students did not ask the patient to state their name and date of birth during the simulation. Verification of the correct patient was not done prior to providing medication. This is a disturbing finding as identification of the correct patient is crucial prior to dispensing medication. A secondary finding from this study was the lack of consideration for language as a barrier to communication with the simulated Vietnamese patient. Students' comments indicate that assumptions were made regarding patient understanding. Care was given to the Vietnamese patient, but without translated dialogue to affirm patient understanding. The students in this study showed similar outcomes to Schlichting's study ${ }^{[22]}$ where health care providers use a "gut feeling" to determine understanding. Student comments demonstrated a lack of cultural sensitivity regarding a patient with LEP. Joint Commission ${ }^{[23]}$ Standards support the provisions of "care, treatment, and services in a manner that is conducive to the culture, language, health literacy, disability, and learning needs of the individual." Singleton and Krause ${ }^{[24]}$ suggest that nurses view language and literacy not in isolation, but as interactive components that must be assessed for each patient. Currently, there is a wide range of practices in addressing culture and language in the hospital setting; while resources may exist, poor practice and processes that are not followed may attribute to the gap in actual and desired practices ${ }^{[25]}$. As students model the clinical environment, attention to protocol and best practice may best support student learning with regards to patient's language needs. LEP and the influence of language on safe medication administration have not previously been reported in the literature and is an area that warrants further study.

\section{Conclusion}

The purpose of this research study was to assess undergraduate nursing students' competency with medication administration to a simulated patient with LEP. Findings from this pilot study indicate students were unable to administer medication safely and were inattentive to the language needs of a LEP patient. Further inquiry into the influence of language as a barrier to medication administration is needed. Additional learning opportunities through simulation may assist students in responsive behaviors that support LEP patients. There is a need in schools of nursing for further experiential learning activities to reinforce safety in medication administration.

\section{References}

[1] Institute of Medicine. To err is human: building a safer health system. Washington, DC: National Academy of Science press, 1999.

[2] Barker, H.M., Flynn, E.A., Pepper, G.A., Bates, G.W. \& Mikeal, R.L. Medication errors observed in 36 health care facilities. Archives of Internal Medicine. 2002; 162: 1897-1903. http://dx.doi.org/10.1001/archinte.162.16.1897

[3] Joint Commission. Preventing medication errors. In R.A. Porche, Jr. (Ed), Front line defense: the role of nurses in preventing sentinel events ( $2^{\text {nd }}$ ed.). Oak Terrace, IL: The Joint Commission, 2007.

[4] Hemingway, S., White, J., Turner, J., Dewhirst, K. \& Smith, G. The medicine with respect project: a stakeholder focus group evaluation. Nurse Education in practice. 2012; 12: 310-315. http://dx.doi.org/10.1016/j.nepr.2012.03.008

[5] Tzeng, H., Yin, C. \& Schneider, T. Medication error-related issues in nursing practice. Medsurg Nursing. 2013; 22(1): $13-16,50$. PMid:23469494

[6] Elliot, M. \& Liu, Y. The nine rights of medication administration: an overview. British Journal of Nursing. 2010; 19 (5): $300-305$.

[7] Harding, L., \& Petrick, T. Nursing student medication errors: a retrospective review. Journal of Nursing Education. 2008; 47(1): 43-47. PMid:18232615 http://dx.doi.org/10.3928/01484834-20080101-05

[8] Institute of Medicine. Race, Ethnicity, and Language Data: Standardization for Health Care Quality Improvement. 2009. Available from: http://www.iom.edu/ /media/Files/Report\%20Files/2009/RaceEthnicityData/Race\%20Ethnicity\%20report\%20brief\%20FINAL \%20for\%20web.pdf 
[9] United States Department of Health and Human Services. Civil Rights. 2014. Available from: http://www.hhs.gov/ocr/civilrights/resources/specialtopics/lep/

[10] Bruce, J. \& Wong, I. Parental drug administration errors by nursing staff on an acute medical admissions ward during day duty. Drug Safety. 2001; 24: 855-862. PMid:11665872 http://dx.doi.org/10.2165/00002018-200124110-00006

[11] Taxis, K. \& Barber, N. Causes of intravenous medication errors: an ethnographic study. Quality Safety Health Care. 2003; 12(5): 343-347. http://dx.doi.org/10.1136/qhc.12.5.343

[12] Brady, A., Malone, A. \& Fleming, S. A literature review of the individual and systems factors that contribute to medication errors in nursing practice. Journal of Nursing Management. 2009; 17: 679-697. PMid:19694912 http://dx.doi.org/10.1111/j.1365-2834.2009.00995.x

[13] Sulosaari, V., Kajander, S., Hupli, M., Huupponen, R. \& Leino-Kilpi, H. Nurse students' medication competence- an integrative review of the associated factors. Nurse Education Today. 2012; 32: 399-405. PMid:21652125 http://dx.doi.org/10.1016/j.nedt.2011.05.016

[14] Hoffman, J.M. \& Proulx, S.M. Medication errors caused by confusion of drug names. Drug Safety. 2003; 26: 445-452. PMid:12735783 http://dx.doi.org/10.2165/00002018-200326070-00001

[15] Valdez, L., deGuzman, A. \& Escolar-Chua, R. A structural equation modeling of the factors affecting student nurses' mediation errors. Nurse Education Today. 2013; 33: 222-238. PMid:22325830 http://dx.doi.org/10.1016/j.nedt.2012.01.001

[16] Honey, M., \& Lim, A. Application of pharmacology knowledge in medication management by final year undergraduate nursing students. Contemporary Nurse: A Journal for the Australian Nursing Profession. 2008; 30(1): 12-19. PMid:19072187 http://dx.doi.org/10.5172/conu.673.30.1.12

[17] Goodstone, L. \& Goodstone, M. Use of simulation to develop a medication administration safety assessment tool. Clinical Simulation in Nursing. 2013; e609-e615. http://dx.doi.org/10.1016/j.ecns.2013.04.017

[18] Bearnson, C., \& Wiker, K. Human patient simulators: a new face in baccalaureate nursing education at Brigham Young University. Journal of Nursing Education. 2005; 44(9): 421-425. PMid:16220650

[19] Ford, D., Seybert, A., Smithburger, P., Kobulinsky, L., Samosky, J., \& Kane-Gill, S. Impact of simulation-based learning on medication error rates in critically ill patients. Intensive Care Medicine. 2010; 36(9): 1526-1531. PMid:20300731 http://dx.doi.org/10.1007/s00134-010-1860-2

[20] Zahara-Such, R., M. Improving medication calculations of nursing students through simulation: an integrative review. Clinical Simulation in Nursing. 2013; 9(9): e379-383. http://dx.doi.org/10.1016/j.ecns.2012.08.003

[21] German, M., Kardong-Edgren, S., Odon-Maryon, T., Hallmark, B., Hurd, D., Rogers, N., Haus, C., McColgan, J., Snelson, C., Dowdy, S., Resurreccion, L., Kuerschner, D., LaMar, J., Tennant, M., and Smart, D. Deliberate practice of motor skills in nursing education: CPR as exemplar. 2011; 32(5): 311-315.

[22] Schlichting, J., Quinn, M., Heuer, L., Schaefer, C., Drum, M. \& Chin, M. Provider perceptions of limited health literacy in community health centers. Patient Education and Counseling. 2007; 69(1): 114-120. PMid:17889494 http://dx.doi.org/10.1016/j.pec.2007.08.003

[23] The Joint Commission. The Joint Commission 2009 Requirements Related to the Provision of Culturally Competent Patient-Centered Care Hospital Accreditation Program. 2013. Available from: http://www.jointcommission.org/assets/1/6/2009_CLASRelatedStandardsHAP.pdf

[24] Singleton, K. \& Krause, E. Understanding cultural and linguistic barriers to health literacy. Online Journal of Issues in Nursing. 2009; 14(3): 1-13.

[25] The Joint Commission. Exploring Cultural and Linguistic Services in the Nation’s Hospitals: A Report of Findings. 2013. Available from: http://www.jointcommission.org/assets/1/6/Report_of_findings_One_Pager.pdf. 